\title{
Significados e percursos da docência
}

Caterine Vila Fagundes ${ }^{1}$

Ana Christina Ghisleni ${ }^{2}$

Tardif (2012) fala sobre a docência como fenômeno social. Objeto de conhecimento científico sim, porém vinculado aos contextos de formação, de construções e de práticas possíveis. As incertezas e as diferenças romperam com a noção de tradição pedagógica, pautada por supostas e falsas homogeneidades. É no contexto da profissionalização docente, de uma disputa marcada por confrontos, contradições e conflitos, que uma nova concepção de docência se impõe. Uma concepção que exige formação qualificada e vinculada às possibilidades e às práticas em diferentes contextos políticos e pedagógicos.

Voltando a Tardif (2012, n.p), vale lembrar que o campo do saber docente se apresenta "muito dividido em disciplinas e teorias múltiplas, que nunca puderam ser unificadas em torno de uma visão comum do saber profissional" e que

\begin{abstract}
é muito difícil isolar a questão dos saberes dos professores das outras dimensões do trabalho docente: formação, desenvolvimento profissional, identidade, carreira, condições de trabalho, tensões e questões sócioeducativas que marcam a profissão, características das instituições escolares onde trabalham os professores, conteúdos dos programas escolares, etc. (TARDIF, 2012, n.p)
\end{abstract}

É com essa configuração que a discussão proposta por esse dossiê se apresenta. É com essa intencionalidade que os artigos aqui apresentados sistematizam um conjunto de ideias, de experiências, de proposições conceituais e metodológicas. Na docência, como em tantos outros fazeres, a atuação está sempre orientada para saberes que se vinculam e se ressignificam a partir de histórias de vida, de conhecimentos de formação e de conhecimentos da vida profissional. As maneiras e as condições de articulação entre esses elementos nunca são unívocas, nem lineares e, tampouco, constantes. Trata-se de uma disputa legítima entre ideias, concepções, entre "quereres" e "fazeres". Trata-se de uma disputa em que não há vencedores, mas, sim, em que se criam novas tendências e possibilidades para a qualificação dos processos educativos. Se existe, aliás, alguma disputa, é justamente nisso que ela reside: no ensinar e no aprender estendido para todas e todos. Trata-se, ainda nos dizeres de Tardif, da impossível desvinculação entre os aspectos normativos e epistemológicos, em que as qualificações econômica, pedagógica, política e cultural preceituadas por Sander em 2007 possam convergir rumo a saberes

\footnotetext{
1 Doutora em Educação, pesquisadora do Núcleo de Políticas e Gestão da Educação da Universidade Federal do Rio Grande do Sul. E-mail: caterine.fagundes@gmail.com

2 Doutora em Educação, professora e pesquisadora do Mestrado Profissional em Gestão Educacional da Unisinos. E-mail: acghisleni@ unisinos.br
} 
e fazeres docentes - ainda parafraseando Sander - pedagogicamente eficientes, politicamente efetivos e culturalmente relevantes.

Assim, abrindo o dossiê, Juliana Hass Massena et al., em Condições de trabalho de professores e diretores de escolas públicas: um estudo sobre a rede estadual de educação do Rio Grande do Sul, evidencia a gravidade do problema de desvalorização da carreira e a necessidade de agregar tal situação à pauta das políticas educacionais. Os autores consideram que é latente a necessidade de pensar a escola como um ambiente educativo onde trabalhar, estudar e formar não sejam atividades desconectadas.

Em O Projeto Político Pedagógico do Curso de Estatistica da Universidade Federal do Rio Grande do Sul: uma análise em relação ao Plano de Desenvolvimento Institucional da UFRGS, Michele da Silva Nimeth Riella e Ana Cristina Ghisleni Identificam elementos relevantes que reforçam a conectividade da gestão ao modelo educacional democrático, social e igualitário. Além disso, apontam que os documentos analisados buscam uma preocupação com a formação do aluno, considerando a interdisciplinaridade, abrangendo diversas áreas do conhecimento, as experiências e compartilhamentos com a pós-graduação, bem como com a extensão.

Olga Gonzàlez Mediel e Veronica Asensio Arjona, em CLIL and music in the child and primary teacher degree, apresentam a experiência positiva, realizada na Universidade de Barcelona, com o sistema CLIL (Aprendizagem Integrada de Conteúdos e Linguagem), que se desenvolve como uma metodologia de ensinoaprendizagem para utilizar nos contextos nos quais o inglês não é a língua materna dos estudantes. $\mathrm{O}$ sistema consiste em utilizar a língua inglesa como idioma veicular no ensino de componentes curriculares não linguísticos para a obtenção dos objetivos curriculares das diferentes áreas.

Na sequência, Renata dos Santos Xavier Sales e Alcione Sousa de Meneses, em A atuação socioeducativa e política do professor do campo e as repercussões de suas ações nas relações escolares e extra-escolares, tratam da figura do professor da educação básica nas escolas do meio rural e da importância do protagonismo docente para o fortalecimento da Educação do Campo. As autoras analisam que o conceito de educação do campo passa pela importância de partilhar o conhecimento de uma forma aberta e crítica, em que possa haver o diálogo não somente sobre os conteúdos, mas também sobre as questões sociais trazidas para o ambiente de sala de aula e extraclasse.

Geníria Almeida dos Santos Souza e Adriane Lizbehd Halmann, em Pergunta de criança: oportunidades formativas para professores em serviço a partir dos questionamentos sobre fenômenos da natureza por crianças do primeiro ciclo da alfabetização, demonstram que ainda é presente uma abordagem conteudista, na concepção de que o docente deve responder as perguntas dos discentes e trazê-los de volta para a aula. Entretanto, após vivenciarem a possibilidade do questionamento como estruturante do planejamento, os docentes afirmaram a possibilidade de construir novas aprendizagens mais significativas, além de considerarem esta uma oportunidade importante de formação docente continuada em serviço. E afirmam que 
o questionamento dos alunos pode ser considerado o ponto de partida e de chegada para a organização da prática pedagógica do professor.

No artigo Escrita Acadêmica: por uma docência autoral, Maria José Nélo, Nayara da Silva Queiroz e Gilvan Santos Gonçalves refletem sobre os significados de uma docência autoral a partir da discussão de uma de suas vias de desdobramento: a escrita acadêmica. E concluem que, sem a devida dedicação e cuidado, nossa escrita será só mais uma entre tantas outras que se assemelham por temática.

Em seguida, Ana Lúcia Fernandes e Ingrid Finkler Cavion, em Diretrizes Pedagógicas e a construção do Projeto Pedagógico local: uma construção coletiva necessária, abordam questões relacionadas à gestão e ao processo de elaboração do Projeto político-pedagógico (PPP), buscando compreender como a coordenação pedagógica lida com questões relacionadas à ressignificação e à inovação nas práticas educativas. As autoras identificaram pontos mais frágeis que podem impactar na produção das subjetividades de alunos e professores e que merecem ser revistos em um processo de fortalecimento institucional.

Por fim, cabe ressaltar que os artigos aqui reunidos procuraram contemplar pesquisadores de diferentes universidades brasileiras e internacionais. Convidam o leitor a dialogar com aportes teóricos e metodológicos oriundos dos significados e percursos da docência. Acredita-se que esses olhares podem contribuir com as investigações em educação, uma vez que propõem indagações enriquecedoras que nos provocam para novos posicionamentos e novos olhares para o campo da prática docente tanto no âmbito pedagógico quanto no âmbito da gestão.

\section{Referências}

SANDER, Benno. Administração da Educação no Brasil. Brasília: Liber, 2007.

TARDIF, M. Os saberes dos professores. In: OLIVEIRA, Dalila Andrade et al. Dicionário de trabalho, profissão e condição docente. Belo Horizonte: UFMG/Faculdade de Educação, 2010.CDROM (não paginado). 


\section{The meanings and paths of teaching}

Tardif (2012) talks about teaching as a social phenomenon. Object of scientific knowledge yes, but linked to the contexts of formation, constructions, and possible practices. Uncertainties and differences broke with the notion of pedagogical tradition, based on supposed and false homogeneities. It is in the context of the teacher's professionalization, of a dispute marked by confrontations, contradictions, and conflicts that a new conception of teaching is imposed. A concept that requires qualified training and is linked to the possibilities and practices in different political and pedagogical contexts.

Returning to Tardif, it is worth remembering that the field of teaching knowledge is "very divided into multiple disciplines and theories, which could never be unified around a common view of professional knowledge" (Tardif, 2012, n.p) and that

\footnotetext{
it is very difficult to isolate the question of the teachers' knowledge from other dimensions of the teaching work: training, professional development, identity, career, working conditions, tensions and socioeducational issues that mark the profession, characteristics of the school institutions where the teachers work, the contents of school programs, etc. (TARDIF, 2012, np) ${ }^{3}$
}

It is with this configuration that the discussion proposed by this dossier presents itself. It is with this intentionality that the articles presented here systematize a set of ideas, experiences, conceptual and methodological propositions. In teaching, as in so many other activities, performance is always oriented towards a knowledge that is linked to and resignified by life stories, the knowledge of training and the knowledge of professional life. The ways and conditions of articulation between these elements are never univocal, nor linear, nor constant. It is a legitimate dispute between ideas, conceptions, between "wanting" and "doing". It is a dispute where there are no winners, but where new trends and possibilities are created for the qualification of the educational processes. If there is, in fact, any dispute, this is precisely what it resides in: teaching and learning extended to all. It is also, in Tardif's words, the impossible disconnection between normative and epistemological aspects, where the economic, pedagogical, political and cultural qualifications prescribed by Sander in 2007 can converge towards the teaching knowledge and practices - still paraphrasing Sander - pedagogically efficient, politically effective and culturally relevant.

Thus, opening the dossier, Juliana Hass Massena et al., In Working conditions for teachers and principals of public schools: a study on the state

\footnotetext{
3 “é muito difícil isolar a questão dos saberes dos professores das outras dimensões do trabalho docente: formação, desenvolvimento profissional, identidade, carreira, condições de trabalho, tensões e questões sócio-educativas que marcam a profissão, características das instituições escolares onde trabalham os professores, conteúdos dos programas escolares, etc. (TARDIF, 2012, n.p)"
} 
education system in Rio Grande do Sul, shows the seriousness of the problem of career devaluation and the need to add this situation to the agenda of educational policies. The authors consider that there is a latent need to think about the school as an educational environment where working, studying, and training are not disconnected activities.

In The Political Pedagogical Project of the Statistics Course at the Federal University of Rio Grande do Sul: An analysis in relation to the Institutional Development Plan of UFRGS, Michele da Silva Nimeth Riella and Ana Cristina Ghisleni Identify relevant elements that reinforce the connectivity of management to the democratic, social and egalitarian educational system model. And they state that the analyzed documents aim at an interest in the education of the student, considering the interdisciplinarity, covering several areas of knowledge, the experiences and sharing with the postgraduation, as well as with the extension.

Olga González Mediel and Veronica Asensio Arjona, in CLIL and music in the child and basic education, present the positive experience, held at the University of Barcelona, with the CLIL system (Integrated Learning of Content and Language), which is developed as a teaching and learning methodology to be used in contexts where English is not the students' mother tongue. The system consists of using the English language as a vehicle language in the teaching of non-linguistic curriculum components to obtain the curricular objectives of the different areas.

Following, Renata dos Santos Xavier Sales and Alcione Sousa de Meneses in The socio-educational and political performance of the rural teacher and the repercussions of their actions on school and extra-school relations, deal with the figure of the teacher of basic education in rural schools and the importance of the teaching role in strengthening rural education. The authors analyze that the concept of rural education involves the importance of sharing knowledge in an open and critical way, where there may be a dialogue not only about the contents, but also about the social issues brought to the classroom environment and extra class.

Geníria Almeida dos Santos Souza and Adriane Lizbehd Halmann in Child's question: training opportunities for teachers in service based on questions about phenomena of nature by children in the first literacy cycle, demonstrate that a content approach is still present, in the conception that the teacher must answer students' questions and bring them back to class. However, after experiencing the possibility of questioning as a structuring of planning, the teachers stressed the possibility of building a new, and more meaningful learning, in addition to considering this an important opportunity for continuing the teacher's training in service. And they state that students' questioning can be considered the starting and ending point for the organization of the teacher's pedagogical practice.

In the article Academic Writing: for an author teaching, Maria José Nélo, Nayara da Silva Queiroz and Gilvan Santos Gonçalves reflect on the meanings of an author teaching from the discussion of one of its unfolding pathways: academic writing. And they conclude that without due dedication and care, our writing will be just one among many others that are similar in theme. 
Then, Ana Lúcia Fernandes and Ingrid Finkler Cavion in Pedagogical Guidelines and the construction of the local Pedagogical Project: a necessary collective construction, address issues related to the management and the process of preparing the political-pedagogical Project (PPP), seeking to understand how the coordination of the pedagogical approach deals with issues related to reframing and innovating in educational practices. The authors identified weaker points that can impact the production of the subjectivities of students and teachers and that deserve to be reviewed in a process of institutional strengthening.

Finally, it should be noted that the articles gathered here sought to include researchers from different Brazilian and international universities. They invite the reader to dialogue with theoretical and methodological contributions from the meanings and paths of teaching. It is believed that these views can contribute to research in education, since they propose enriching questions that provoke us to new positions and new perspectives in the field of teaching practice, both in the pedagogical scope and in the scope of management.

\section{References}

SANDER, Benno. Administração da Educação no Brasil. Brasília: Liber, 2007.

TARDIF, M. Os saberes dos professores. In: Dalila Andrade Oliveira et al. Dicionário de trabalho, profissão e condição docente. Belo Horizonte: UFMG/Faculdade de Educação, 2010.CDROM (não paginado). 


\section{Significados y recorridos de la docencia}

Tardif (2012) habla sobre la docencia como fenómeno social. Objeto de conocimiento científico sí, pero vinculado a los contextos de formación, de construcciones y de prácticas posibles. Las incertezas y las diferencias rompieron con la noción de tradición pedagógica, pautada por supuestas y falsas homogeneidades. En el contexto de la profesionalización docente, de una disputa marcada por enfrentamientos, contradicciones y conflictos, una nueva concepción de la docencia se impone. Una concepción que exige formación cualificada y vinculada a las posibilidades y a las prácticas en diferentes contextos políticos y pedagógicos.

Volviendo a Tardif, vale recordar que el campo del saber docente se presenta "muy dividido en disciplinas y teorías múltiples, que nunca pudieron ser unificadas en torno de una visión común del saber profesional" (Tardif, 2012, n.p) y que

es muy difícil aislar la cuestión de los saberes de los profesores de las otras dimensiones del trabajo docente: formación, desarrollo profesional, identidad, carrera, condiciones de trabajo, tensiones y cuestiones socioeducativas que marcan la profesión, características de las instituciones escolares donde trabajan los profesores, contenidos de los programas escolares, etc. (TARDIF, 2012, n.p) ${ }^{4}$

Es con esa configuración que la discusión propuesta por este dossier se presenta. Es con esa misma intención que los artículos aquí presentados sistematizan un conjunto de ideas, de experiencias, de proposiciones conceptuales y metodológicas. En la docencia, como en tantos otros campos, la actuación está siempre orientada hacia saberes que se vinculan y se resignifican a partir de historias de vida, de conocimientos de formación y de conocimientos de la vida profesional. Las maneras y las condiciones de articulación entre esos elementos nunca son unívocas, ni lineares y, tampoco, constantes. Se trata de una disputa legítima entre ideas, concepciones, entre "quereres" y "haceres". Se trata de una disputa donde no hay vencedores, pero donde sí se crean nuevas tendencias y posibilidades para la cualificación de los procesos educativos. Al respecto, si existe alguna disputa, es justamente en eso que ella reside: en el enseñar y en el aprender extendido para todas y todos. Se trata, en las palabras de Tardif, de la imposible desvinculación entre los aspectos normativos y epistemológicos, donde las competencias económica, pedagógica, política y cultural, establecidas por Sander en 2007, puedan convergir rumbo a saberes y haceres docentes - parafraseando a Sander - pedagógicamente eficientes, políticamente efectivos y culturalmente relevantes.

Así, abriendo el dossier, Juliana Hass Massena et al., en Condições de trabalho de professores e diretores de escolas públicas: um estudo sobre a rede

\footnotetext{
4 “é muito difícil isolar a questão dos saberes dos professores das outras dimensões do trabalho docente: formação, desenvolvimento profissional, identidade, carreira, condições de trabalho, tensões e questões sócio-educativas que marcam a profissão, características das instituições escolares onde trabalham os professores, conteúdos dos programas escolares, etc. (TARDIF, 2012, n.p)"
} 
estadual de educação do Rio Grande do Sul, evidencian la gravedad del problema de desvalorización de la carrera y la necesidad de incluir esta situación en el debate sobre políticas educacionales. Los autores consideran que es latente la necesidad de pensar la escuela como un ambiente educativo donde trabajar, estudiar y formar no sean actividades desconectadas.

En O Projeto Político Pedagógico do Curso de Estatistica da Universidade Federal do Rio Grande do Sul: Uma análise em relação ao Plano De Desenvolvimento Institucional da UFRGS, Michele da Silva Nimeth Riella y Ana Cristina Ghisleni identifican elementos relevantes que refuerzan la conectividad de la gestión al modelo educacional democrático, social e igualitario. Ellas evidencian que los documentos analizados buscan una preocupación con la formación del alumno, considerando la interdisciplinaridad, abarcando diversas áreas del conocimiento, las experiencias y vínculos con el posgrado, así como con la extensión.

Olga González Mediel y Verónica Asensio Arjona, en CLIL and music in the child and primary teacher degree, presentan la experiencia positiva, realizada en la Universidad de Barcelona, con el sistema CLIL (Aprendizaje Integrado de Contenidos y Lenguaje), que se desarrolla como una metodología de enseñanzaaprendizaje para utilizar en los contextos en los cuales el inglés no es la lengua materna de los estudiantes. El sistema consiste en utilizar la lengua inglesa como idioma vehicular en la enseñanza de componentes curriculares no lingüísticos para la obtención de los objetivos curriculares de las diferentes áreas.

A seguir, Renata dos Santos Xavier Sales y Alcione Sousa de Meneses en A atuação socioeducativa e política do professor do campo e as repercussões de suas ações nas relações escolares e extra-escolares, analizan la figura del profesor de la educación básica en las escuelas del medio rural y la importancia del protagonismo docente para el fortalecimiento de la Educación rural. Las autoras afirman que el concepto de educación rural establece la importancia de compartir el conocimiento de una forma abierta y crítica, donde pueda haber diálogo no solamente sobre los contenidos, sino también sobre las cuestiones sociales que se integran en el ambiente de la clase y fuera de ella.

Geníria Almeida dos Santos Souza y Adriane Lizbehd Halmann en Pergunta de criança: oportunidades formativas para professores em serviço a partir dos questionamentos sobre fenômenos da natureza por crianças do primeiro ciclo da alfabetização, demuestran que todavía está presente un abordaje de contenido, en la concepción de que el docente debe responder a las preguntas de los discentes y hacerlos retornar a la clase prevista. Sin embargo, después de haber vivido la posibilidad de cuestionamiento como estructurante de la planificación, los docentes afirmaron la posibilidad de construir nuevos aprendizajes más significativos, además de que consideran esta situación una oportunidad importante de formación docente continuada en servicio. Ellos afirman también que el cuestionamiento de los alumnos puede ser considerado el punto de partida y de llegada para la organización de la práctica pedagógica del profesor. 
En el artículo Escrita Acadêmica: por uma docência autoral, Maria José Nélo, Nayara da Silva Queiroz y Gilvan Santos Gonçalves reflexionan sobre los significados de una docencia autoral a partir de la discusión de uno de sus resultados: la escritura académica. Y concluyen que, sin la debida dedicación y cuidado, nuestra escritura será solo una más entre tantas otras que se asemejan por temática.

En seguida, Ana Lúcia Fernandes e Ingrid Finkler Cavion en Diretrizes Pedagógicas e a construção do Projeto Pedagógico local: uma construção coletiva necessária, abordan cuestiones relacionadas a la gestión y al proceso de elaboración del Proyecto político-pedagógico (PPP), buscando comprender cómo la coordinación pedagógica trabaja con cuestiones relacionadas a la resignificación y la innovación en las prácticas educativas. Las autoras identificaron los puntos más frágiles que pueden impactar en la producción de las subjetividades de alumnos y profesores y que merecen ser revisados en un proceso de fortalecimiento institucional.

Por fin, cabe resaltar que los artículos aquí reunidos buscaron contemplar investigadores de diferentes universidades brasileras e internacionales. Los textos invitan al lector a dialogar con aportes teóricos y metodológicos oriundos de los significados y recorridos de la docencia. Se cree que esas miradas pueden contribuir con las investigaciones en educación, una vez que proponen indagaciones enriquecedoras que nos interpelan para nuevos posicionamientos y nuevas miradas para el campo de la práctica docente tanto en el ámbito pedagógico como en el ámbito de la gestión.

\section{Referencias}

SANDER, Benno. Administração da Educação no Brasil. Brasília: Liber, 2007.

TARDIF, M. Os saberes dos professores. In: Dalila Andrade Oliveira et al. Dicionário de trabalho, profissão e condição docente. Belo Horizonte: UFMG/Faculdade de Educação, 2010.CDROM (não paginado). 